\title{
New Perspectives on Real Estate Valuation
}

\author{
Jeffrey P. Cohen ${ }^{1}$ (10 $\cdot$ Michael LaCour-Little ${ }^{2}$
}

Published online: 9 November 2019

(C) Springer Science+Business Media, LLC, part of Springer Nature 2019

\section{Guest Editors' Introduction}

On October 21-22, 2018, Fannie Mae hosted a Symposium on Real Estate Valuation in Washington, D.C. The event was developed in conjunction with the Appraisal Foundation, and the University of Connecticut's Center for Real Estate and Urban Economic Studies. Dozens of manuscripts were submitted and, after Program Committee Review, fifteen papers were accepted for presentation during the two-day event. After receiving comments from a discussant on the program, authors were invited to submit revised manuscripts for consideration at the journal.

Jeffrey Cohen of the University of Connecticut and Michael LaCour-Little of Fannie Mae served as guest special issue editors. In order to avoid the appearance of any conflict of interest, papers with University of Connecticut co-authors were handled by Michael Lacour-Little and papers with Fannie Mae co-authors were handled by Jeffrey Cohen. After a blind peer review process for those papers submitted for consideration in this special issue of the journal, a total of eleven manuscripts were accepted for publication. These papers are now published in this two-volume special issue of the Journal of Real Estate Finance and Economics.

The papers in this volume can be classified in two sub-areas within valuation: appraisal and assessment. While valuation is the underlying theme of both appraisal and assessment, the papers in this special issue follow quite different approaches, including some that focus on novel innovations in econometric techniques, others with an international focus, and one using popular machine learning techniques. Together these papers provide important insights into real estate valuation, both for multifamily and single-family segments of the market.

Jeffrey P. Cohen

Jeffrey.Cohen@uconn.edu

Michael LaCour-Little

michael_lacourlittle@fanniemae.com

1 Center for Real Estate and Urban Economic Studies, University of Connecticut, Storrs, CT, USA

2 Fannie Mae, Washington, DC, USA 
We would like to thank the additional members of the Program Committee, which included Robert B. Avery, Federal Housing Finance Agency; John Brenan, The Appraisal Foundation; Daniel McMillen, University of Illinois; Raven S. Malloy, Federal Reserve Board of Governors; and Peter M. Zorn, Freddie Mac. The views expressed are the authors' alone and not those of Fannie Mae or the Federal Housing Finance Agency. 